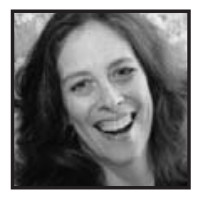

\title{
Commentary:
}

\section{Creating a Curriculum of Intention and Justice}

\author{
Michelle Fine, The Graduate Center, City University of New York
}

\section{ABSTRACT (Press Here for Sound)}

In this essay we will wander into the vibrant space of a college in prison, schools and communities in which research projects have been initiated by coalitions of youth and elder activists. And we will bear witness to a lived curriculum-curriculum in the making. Shaped by the wisdom of youth and adults and the conversations between, these projects breathe a fierce intentionality to expose the contours of social injustice and a thick desire to reveal the spaces of possibility for educational engagement. At the intersection of deep inquiry, the politics of survival and affective engagement, these projects represent a way to re-vision curriculum building as a public project fed by participation, across generations, fueled by a desire for a life not yet. In each case, youth, educators and elders came together to deliberate about the purpose of the work, the depth of participation, the nature of the processes, the shape of the products we would create, and the range of worthy audiences to whom we would hold ourselves accountable.

\subsection{0 .08}

ast night, I cried, again, in the gymnasium of a women's maximum security prison. The occasion was a memorial service for my dear friend Thea Jackson who, in 1995, brought college back to Bedford Hills Correctional Facility, after then President Clinton severed prisoners' rights to federal Pell grants. ${ }^{1} \mathrm{~A}$ baby-faced 18-year-old covered with a head scarf sat next to a grey-haired aging woman who appeared well beyond 60 . Each of the 50 or so college students and 
graduates in the room is serving eight, 10, 12, 15, 20, 25 year sentences, life sentences for crimes of drugs and/or violence. We were choking, silently, on the knowledge that more than 500 years of prison time metastasized the air in the gym.

JC, serving 75 to life, opened the evening, "I have been a prisoner here longer than many of you have been alive." Correction officers circled: four White men, and one African American woman, encasing us as an (in)human(e) shield, an intimate embodiment of the spiked barbed wire outside.

Across 90 minutes, scores of women poured forth at the microphone, singing, dancing, presenting gifts of thanks to the Jackson family, reading from a box of "Letters of Thanks for College" written by students and graduates of the college program, and presenting emotion-filled speeches about why college matters "for me, my children, my grandchildren-even my sisters and brothers." We all listened to women speak the magic of education in their lives.

Joan² opened:"I am a mother and now a grandmother. This past June I graduated, here in this prison, on that stage, valedictorian of my class. In the audience sat my five children from Staten Island and my grandbaby. They were so proud. Not only am I getting educated here, but two of my kids are now in college because they said, 'Mom if you can do this from in here, we can outside.'I thank Thea and the college programnone of this would have been possible without you."

Medoora picked up the rhythm:"I came to Bedford 20 years ago, not even with a GED. Now I have an Associates, Bachelor's and I'm onto my Masters. I read literature and history, I write poetry, have new thoughts and am interested in how others see the world. Mostly I realize I don't have to be driven by emotion."

Cheryl, now released, offered us final words directed at Jack, Thea's husband: "Jack, you know Thea tricked me into college. She told me, as Black women we need to be educated to get good jobs. She told me that her grandfather, a former slave, started the first high school for so called 'colored children' in Virginia. So I believed her. I thought I was going to college in here so I could get a good job when I got out. But what I learned is that college is really about meeting myself, again, opening to others, understanding the shoulders I stand on and my obligation to open doors for you-my sisters-when you come out. College is about responsibility and trust, giving back, stretching. You're not going to believe this, but I just came back from giving a talk to the Department of Corrections in South Carolina, and then in Virginia - a Black woman, former inmate, speaking to DOCS in the Confederacy about educating women in prison! Thea tricked me when she was alive, and now she's got me working!" 
I do not want to sound romantic. It was an awful and wonderful night. The women are locked away from children, freedom, family, friends, fresh air-for so long for crimes of poverty, pain and violence-against them and sometimes by them. For mistakes that recidivism statistics bear out, women are extremely unlikely to commit again (in a recent recidivism study of women who have served 20 years or longer, we found a $0 \%$ recidivism for a new crime after three years). But college, in this sadistic place called prison, has carved open a small space to be; to be with; to be for. Women gather, intellectually and emotionally, in community, to read, write, recast the past and redesign the future; planting seeds for self and their children, grandchildren, sisters and brothers.

Andora's poetry filled the musky gym with sweet aromas. Her words painted and scented our collective imaginary: "Thea's vision was a garden, a garden of educated women, women of all colors. And from a seed, look at what has grown." At that moment, clothed in white shirts and prison-green pants, all of the students and the graduates rose. They carried themselves and each other to the front of the room, revealing the colors, contours, depth and community of Thea's vision for education in prison.

Over apple juice and stale cookies, "civilians" were allowed to speak with the students and the graduates, for just a bit. I hugged Donna, whom I had not seen in maybe six years since we completed our participatory evaluation of the college in prison program and were told not to return to the prison. As I approached Aisha, another co-researcher from the Changing Minds project (Fine et al., 2001), a short, wire-rimmed, White male guard pulled me aside with a quiet warning,"If you hug too many of the women, they will have to be strip searched before going back to their cells." A Foucaultian nightmare of surveillance and the Panopticon; Marquis de Sade or maybe he was just being nice.

\section{Education for Liberation, Housed in an Institution of Coercive State Power; a Garden in Hell.}

Driving home from the prison, my face was tear-stained, as it has been on every other ride home. My body saturated with an exhausting combination of joy and outrage. At 9:15 on a rainy evening, my car sped along the windy, death-defying Saw Mill River Parkway. I accelerated, exceeding the speed limit, anxious to hold and be held by David, my partner, and our son Caleb, longing for heat, music and a glass of wine. My mind flipped into reverse. Three years ago, when Caleb was in fourth grade, he had fallen, quite by accident, during recess. His body weight landed directly onto 
the leg of another child, whose femur broke. Ambulances arrived. Schoolyard rumors circulated, "Police're coming to get you." Caleb shivered in tears of regret and petrifying fear; confused about cause and responsibility and mistakes and consequences. His friend, Shadel comforted him, placing an arm around his left shoulder and a whisper in his left ear: "Let's tell the teachers I did it. They already think I'm a bad kid and you're good. Won't matter if I get blamed."

Caleb is White; Shadel is Black. Maybe this is one more coincidence in a long line of racially aligned "coincidences" we have witnessed in the 15 years of attending the courageous, contentious, ambitious and hypocritical, desegregated schools in our community in New Jersey.

I volunteer in Caleb's classroom once a week and have come to know the predictable dynamics that unfold before, during and after Shadel [this year] performs "bad boy"; the one who acts out, especially when he does poorly on a test. And I know what happens to children who come to believe they are not smart, not college material, "bad" students who do not graduate ... How have these young bodies been marked so fundamentally, so young? How have we burned into their skin the tattoos of who is a good kid and who is bad, by age nine? How does education in one setting, a prison, take up the work of liberation, and yet education in another setting - $a$ relatively sweet, desegregated, trying-if-clumsily-what-the-rest-of-the-country-hasrefused-to-address public school-take up the work of branding?

There is a well-lubricated path for Shadel leading to Bedford or Sing Sing or ...; an automatic walkway, like in airports, as Beverly Tatum (2003) has described racism. He does not have to do much to be facilitated down the path. But someone would have to do something extraordinary to yank him off course. And this is where I want to talk about intentionality and the project of public education within profoundly unjust circumstances.

\section{Intentionality and Participatory Democracies}

And so you ask me, how do you define curriculum? What should we be teaching? I do not pretend to know, but I do believe that the question of curriculum cannot be severed from a larger conversation about the intent of public education. Whether we teach in exclusively elite, desegregated or exclusively low income schools, before we ask what we should teach, we must ask ourselves what our project 
is? What do young people need to know in order to flourish and challenge a world marked by enormous, scathing inequities in income and wealth, suffocating in an atmosphere of fear and deep existential uncertainty? We might ask, further: Why have we not gathered communities, educators and youth to consider this question of purpose; how is it possible that we have ceded this question to the testing industry?

Let me return to the prison to think about the elements that enabled us to create a school where education flowed with liberatory possibility. After the Pell grants disappeared, a series of meetings were called by the women in prison and Thea from the local community. Women college presidents, community advocates, women in the prison and representatives of the prison administration gathered weekly to consider how we might resurrect college without federal funds. After about six months, with the enormous leadership of Regina Peruggi, President of Marymount College, a consortium of universities was established, each contributing two faculty per semester. College Bound was up and running at Bedford Hills Correctional Facility with varied participatory committees of governance. The Inmate Committee, with the faculty, generated policies about what students would pay (even minimally, as they decided public opinion would never tolerate free education); how discipline would be administered for cutting classes; how remediation would be organized; that sociology would be the primary degree; that all students should be expected to mentor the next incoming class in the prison or once they are released. With the administration and the College Presidents, the women recommended that annually the College Bound program bestow gift of a college scholarship to the child of a woman in prison, the child of a corrections officer and the child of a victim of violent crime. The Presidents of the consortium colleges worked collaboratively on curriculum, books, how to integrate college-in-prison into their admissions materials, and on strategies to recruit faculty to the prison. The administration worked on keeping Albany ${ }^{3}$ happy and figuring out how to offer courses for corrections officers. Within a few years, a participatory research collaborative of seven women from inside the prison and six of us from outside materialized, and we conducted a participatory evaluation, documenting the dramatic positive impact of college in prison on recidivism rates, tax savings, a reduction in disciplinary incidents and peace in the prison and increased interest in college, evidenced by children of prisoners.

With participatory beginnings, even today, in the prison, the educators, community advocates and the women collect ourselves in a self-conscious circle of intent. They/we gather around a "thick desire" (Fine \& McClelland, 2006) for education as liberation, although we never use those words; where respect, responsibility, rigor and community carve collaboratively a small space that stretches toward justice. With 
full knowledge that women in prison are among the most demonized people in the nation, College Bound was found in the soil of radical educational intentionality, dedicated to building and sustaining a space of exception and possibility.

Ironically, I do not know when/if the teachers in Caleb's public elementary school have ever been asked to think, together (much less with community and students) through the swamps of racism, poverty, privilege and justice about educational intent. Ensnared in the rhetoric of testing and No Child Left Behind (NCLB), packaged curricula and packaging children, even talented, justice-oriented educators have difficulty finding a corner where there is enough oxygen to sustain a serious conversation about purpose in the morass of grotesque social inequalities. Of course, no one in this school actively set out to convince Shadel that he is bad. To the contrary, most of the educators here are thoroughly committed to equitable, desegregated education. But perhaps the question about intentionality and purpose is less about whether or not a school intends to reproduce race and class inequity, and more about whether or not a school organizes itself to interrupt the reproduction of class and race inequities. Under what conditions do public schools refuse to collude in the ritual burning of the flesh? What would curriculum look like if communities, educators and youth - in rich, poor and mixed communities - were invited to engage critically in a collaborative inquiry project about the role of schools within contexts of pervasive (in)justice?

Perhaps I am off topic, and then again maybe I am drilling centrally into the muck of curriculum wars. If we avoid questions about purpose and the educational project within contexts of perverse inequality, then talk of curriculum seems like an exercise in dissociation-a psychic splitting off from trauma. And so I will end with some images of middle and high school curricula kneaded at the intersection of intentionality, participation and democracy: where educators, community and youth have collaborated on projects of meaning and inquiry; projects cultivated with messy cross-generational participation, unearthing varied forms of knowledge and producing materials of use.

\section{PAR Projects: Intentionality and Participation in Profoundly Unjust Times}

Over the past decade, members of the Participatory Action Research Collective (PARc) at the Graduate Center of the City University of New York have worked with dozens of youth and educators on PAR projects. Young people in school and out, with varied adults, have designed research to excavate critical knowledge held in the bodies and memories of those long dismissed as not knowing and those 
long revered as knowers. These projects self-consciously recruit both youth of privilege and marginalization to understand how their lives are linked, how privilege and oppression eat off of each other and how new knowledge can be borne when dynamics of injustice and possibility are interrogated in contexts that Maria Elena Torre (2009) would call contact zones. Together we have studied and published on educational engagement and opportunities denied; the history of desegregation; youth experience of homophobia and high-stakes testing;young people's judgments about education, health care and the criminal justice system. We have examined the impact of gentrification, privatization and mass incarceration on urban youth, and we have published and performed our findings with and to communities of educators, elders, activists and other youth.

I want to browse through a few projects to reveal the flesh of intentionality and participation as crucial elements of lived curriculum.

In 1998, Bernandette Anand and I co-taught an Oral History course at a middle school in Montclair, New Jersey where we trained the students to be oral historians of the struggles of desegregation in their community. For four sessions of nine weeks each, we met with one quarter of the seventh grade class at Renaissance Middle School to review and then select relevant newspaper articles from the 1940s through the 1970s, creating a time line of key protests, turning points, legislative moments, victories and defeats, identifying prominent and everyday activists in the struggle for desegregation. The youth contacted the elders, practiced interview questions, learned about "leading" questions and what to do when an elder goes off topic. They begged people who had organized against integration to come in for an interview, but could not get any to agree. With an archive of more than 20 interviews conducted with a diverse sample of educators, activists, parents and adults who were all students in the 1960s, we coded the material and produced a youth- and adultfriendly book, published by Teachers College Press, Keeping the Struggle Alive: Studying Desegregation in Our Town (Anand, Fine, Perkins, \& Surrey, 2002).

With similar commitments, but working with a range of 13 schools districts, in 2001, Superintendent Sherry King of Mamaroneck, New York received a grant to bring together a set of superintendents from "desegregated" suburban districts to research the racial "achievement gap." King asked the PAR Collective at the Graduate Center to design the research that would focus on students. We agreed with the proviso that we would conduct research with, not on or for, students, and designed a PAR project with research teams comprised of high achieving and not-yet-achieving youth from 12 desegregated suburban schools and a few small urban schools from New York City. 
At our first Research Camp, an overnight at St. Peter's College, we brought together more than 50 young people from suburbs and cities, wealth and poverty, foster care and summer homes, advanced placement/honors class and special education, to be taught about research methods and ethics: theory, survey development, and focus group interview protocols. We explained that students and push outs ${ }^{4}$ hold significant insights about the causes, contours and consequences of the achievement gap; that they would know best what questions to ask of their peers and how to ask them.

Early in that weekend, Terese, a young woman who had seemed skeptical thus far, spoke up:"I'm willing to do this research, but only if you call it an opportunity gap, not an achievement gap. When you say achievement it puts the blame on us; when you say opportunity, it shines a light on the structures available to us." And so we began.

By the second research camp, we created a survey on educational opportunities, attitudes, biographies and hopes-filled with Likert scales, cartoons, openended questions and youth artistic designs. The survey was translated into Spanish, French/Creole, and Braille. Distributed to 12,000 ninth and twelfth graders across 13 districts, it was completed by more than 9,000 youth.

At camp \#3, young people and adults analyzed and coded the quantitative and qualitative material by respondents' race/ethnicity, social class, disability and geography, and mapped the perversely differential opportunities available across different financed urban and suburban districts and then by race/ethnicity and class, within the same schools; the distinct experiences of being welcomed or scorned by educators; the sense of belonging or being marginalized within the same building.

After this session, teams of diverse students and educators presented the findings to schools, communities, youth organizations and at educational conferences including the Cross Cultural Roundtable at Teachers College, Columbia University. Young people also wrote articles for journals/magazines/newspapers, including Rethinking Schools and the Annenberg Newsletter.

In the summer of 2003, we held our last series of camps-the Arts, Social Justice and Social Research Institute. We recruited 13 youth to review all the findings and place them in historical context of national struggles for integration. An intensive week was designed with a series of seminars, workshops with choreographers and spoken word artists. Every morning the young people sat in conversation with civil 
rights leaders, lawyers, educators, Black Panthers and Young Lords, feminists and queer activists tracking the history of civil rights as the political precursor to so many other movements for liberation. In the afternoon, the youth worked with dancer/choreographer Ronald K. Brown from the dance troupe Evidence, and spoken word artists to craft performances of the data, embodying, reflecting and resisting the historic struggles for educational justice and the unfulfilled promise of Brown v. Board of Education.

Together we created Echoes of Brown, a montage of dance, politics, history, inquiry and spoken word, by youth and elders. Performed for an audience of 800 in May 2004 to mark the 50th anniversary of Brown v. Board of Education, Echoes was published as a book and a DVD by Teachers College Press, including the performances, the spoken word pieces, and the interviews with elders, including poet Sonia Sanchez, activist Thea Jackson, Judge Jack Weinstein, civil rights attorney Arthur Kinoy and others (Fine et al., 2004).

Most recently, we have launched another project, Polling for Justice (PFJ), a third example of a deeply intentional, highly participatory, quite messy, multiconstituency educational project involving elders, youth and educators. A youth-led survey of young people's experiences of health care, education and criminal justice in New York City, PFJ involves a mixed-methods design in which youth have crafted a survey and focus group protocols and are analyzing official data, documenting the uneven topography of educational and health care opportunities, and the disproportionate policing of young bodies of color. After six months of youth research camps, the survey is being piloted, filled with provocative questions that signal young people's desperate sense of human insecurity and strong desire to be embraced by a society that cares about its young. In the process, they have learned the skills of research, literature reviews, social analysis and writing; they have found community among diverse peers and adult allies.

Across the prison project and these three PAR designs, we bear witness to lived curriculum - curriculum in the making. The projects were shaped by youth and adults, with a fierce intentionality to expose the contours of social injustice and thick desire to reveal the spaces of possibility for educational engagement. At the intersection of rigor, relevance and engagement, these projects represent a way to re-vision curriculum building. In each case, youth, educators and elders came together to deliberate about the purpose of the work; the depth of participation; the nature of the processes; the shape of the products we would create; and the range of audiences to whom we would hold ourselves accountable. 


\section{Notes}

1. Prior to 1994, Pell grants had funded college within 350 U.S. prisons, at which point prisoners were deemed ineligible. After the Violent Crime Act became law, prisoners were no longer eligible for federally funded college assistance. In 1996, eight prisons offered college programs.

2. All names from this point onward are pseudonyms.

3. State capital officials in Albany, New York.

4. Push outs are students who have been denied high school diplomas due to various policies and practices increasingly characteristic of inequitable urban schools in which there are many unqualified educators, high teacher turnover, inadequate laboratories and facilities, and high-stakes testing which determines whether or not a student will graduate.

\section{References}

Anand, B., Fine, M., Perkins, T., Surrey, D. and the graduating class of 2000 Renaissance middle School (2002). Keeping the Struggle Alive: Desegregating Our Town. New York: Teachers College.

Fine, M., \& McClelland, S. (Fall 2006). Sexuality education and desire: still missing after all these years. Harvard Educational Review, 76, 3, 297-338.

Fine, M., Roberts, R., Torre, M., Bloom, J., Burns, A., Chajet, L. et. al (2004). Echoes of Brown: Youth documenting and performing the legacy of Brown v. Board of Education. New York: Teachers College Press.
Fine, M., Torre, M., Boudin, K., Bowen, I., Clark, J., Martinez, D. et. al (2001). Changing minds: The impact of college in a maximum security prison. Retrieved April 29, 2009, from http://web.gc.cuny.edu/che/changingmin ds.html.

Tatum, B. (2003). Why are all the black kids sitting together? New York: Basic Books.

Torre, M. (March 2009). Participatory action research and critical race theory: fueling spaces for nos-otras. The Urban Review, 41, 1, 106-120. 


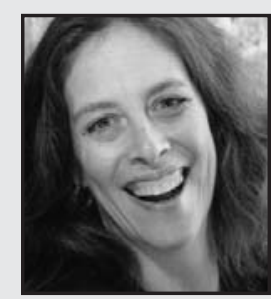

Michelle Fine is a Distinguished Professor of Social Psychology, Women's Studies and Urban Education at the Graduate Center, CUNY. She has taught at CUNY since 1992 and is a founding member of the Participatory Action Research Collective at the Graduate Center at the City University of New York. From 1981-1992, she was on the Human Development faculty at the University of Pennsylvania.

Her research has been organized through participatory action research and focuses on how youth think about and contest injustice in schools, communities and prisons. Recent awards include the 2008 Social Justice Award from the Cross Cultural Winter Roundtable, the 2007 Willystine Goodsell Award from the American Educational Research Association, and the 2005 First Annual Morton Deutsch Award.

LINK TO:

http://web.gc.cuny.edu/psychology

http://web.gc.cuny.edu/che/start.htm

http://web.gc.cuny.edu/che/changingminds.html 